\title{
El juego de las decapitaciones de Lezama Lima
}

In Memoria

Jaime Hernán Uribe Velásquez

Lezama Lima es un autor representativo de la literatura del boom, este destacado autor cubano nos lega su obra Paradiso, lectura obligada de alguien que se precie de ser lector. Su obra, aunque algo complicada, es muy representativa ya que tiene algo de fantástica y fantasiosa. Es una obra con un estilo muy propio.

El boom recurre a medios muy innovadores en la literatura, en su obra, Lezama Lima tiene mucho de esos artificios (como el uso de palabras que aparentemente están fuera de contexto). La literatura latinoamericana del siglo XX antes y después del boom llama mucho la atención de los lectores de todo el mundo y si tanto se hablaba de los autores latinoamericanos por algo debió ser.

\section{El juego de las decapitaciones}

El estilo de Lezama Lima tiene algo de ecléctico. En El juego de las decapitaciones recurre a expresiones que no son ni del tiempo, ni del lugar referido. Al valerse de temas de otros lados y de otros tiempos se apropia de una libertad que le da un sentido original a su narrativa. "Codiciaba una piedra de imanes siberianos, un zorro azul." La piel del zorro azul, es muy apreciada y al parecer era de mucho valor en aquellas tierras asiáticas. Lo primero que me viene a la mente es la vigorización que el desollar animales transmite, pero no se hace alusión a la despellejada sino a lo lujosa que es esta piel.

Es muy grande la riqueza de los artilugios que nos permiten jugar con las palabras no sin establecer ciertos límites que pueden sintetizar o expandir lo que se quiere decir. "Acariciaba también la idea de sentarse en el Trono." Parece aludir a una fantasía, una fantasía no muy lejana de su alcance.

Le vienen a uno a la mente las imágenes que aluden a un lejano país del cual el autor conoce mucho. El hecho de ser un juego cortesano llena de pompa a la narración de El juego de las decapitaciones. "Trasponía El Amarillo, penetrando en los puertos". Si uno no tiene el más mínimo conocimiento de los accidentes geográficos se puede valer 
del contexto para entender que se hace referencia a un río de gran cauce. El Amarillo, así no más. No dice el nombre en chino, así como tampoco dice el nombre del Real. De hecho queda más fácil de entender decir "El Amarillo" que el Huang-ho.

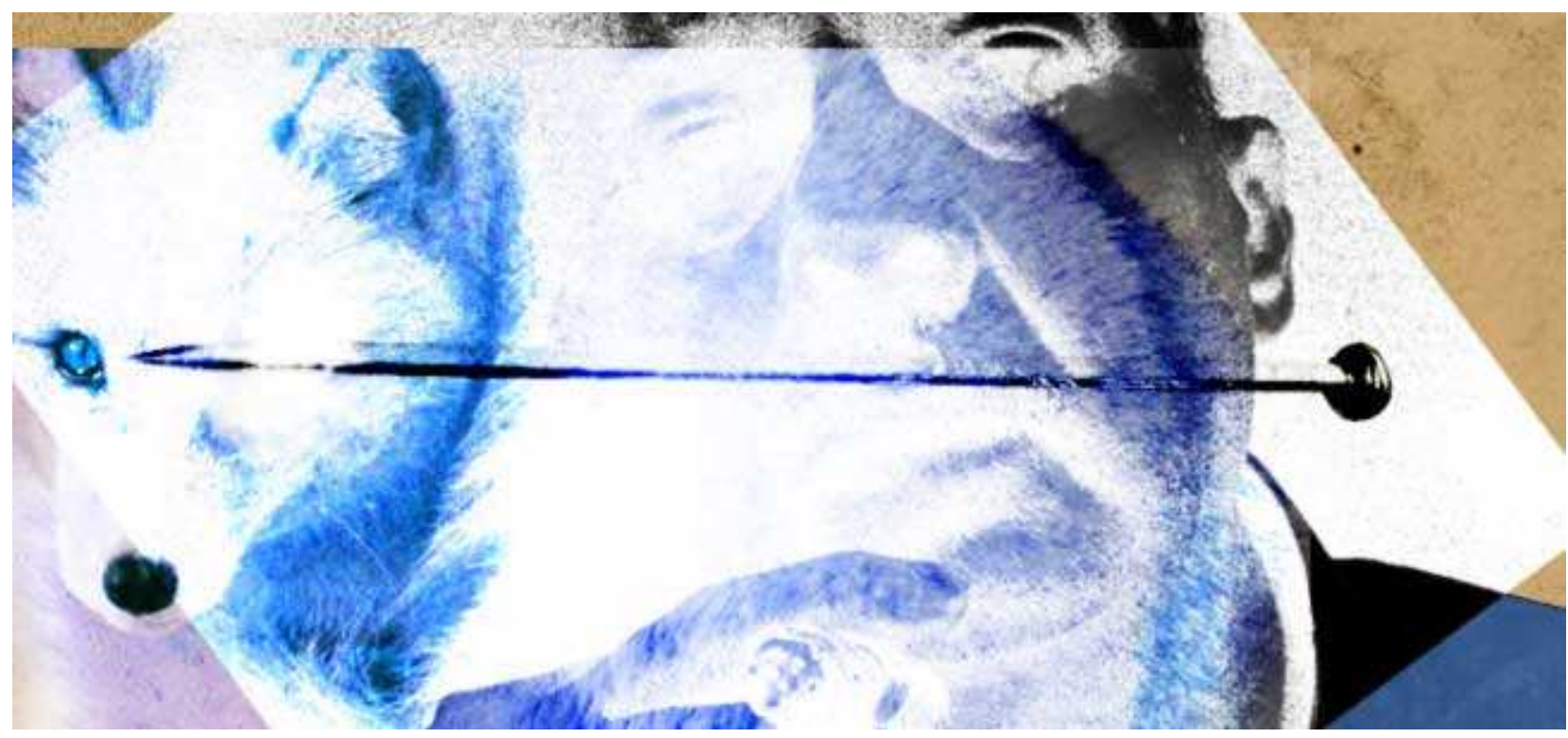

"La pólvora, madre de las flores voladoras". Se hace la semejanza entre los juegos pirotécnicos y flores multicolores. Todo ese esplendor cortesano se llena de barroquismo pero no con una suntuosa adjetivación sino con imágenes grandilocuentes.

Las grandes distancias parecen expandidas más aún por la prosa del autor cubano. "Doce perros voladores para escapar hacia el norte." Es una manera muy dilatada de hacer alusión a un trineo. De alguna forma todos estos episodios pretenden llenar de grandilocuencia esta intriga cortesana. "Parecían pájaros que transportasen en su pico nidos de fuego." De nuevo la impresión que causan en el espíritu las lucecillas en lontananza. "Y se mostraban en innumerables rostros". Otro modo de expandir una cosa que se puede decir en solo una palabra.

No hay pasividad en este relato. Todo es actividad pura. No hay espacio para contempladores y poetas, aquí todo es intriga palaciega. "Clavándole el gesto como un alfiler largo para que no se le escapase." Es una vía para aludir a una mirada penetrante. De pronto parece que el alfiler cobra vida.

Hay muchos recursos en la literatura para decir cosas bien dichas. Sin embargo el texto total puede tener mucho de figura. De alguna forma se une en un todo cada una de las partes, unidas entre sí inter e intrasubjetivamente. La objetividad que la hace legible se pega de la sutileza para no hacer incomprensibles los textos. Aunque Lezama Lima es un poco oscuro, al cabo del texto, como un todo, es legible, como inteligibles las partes.

Acaba el relato con otra muerte luego de un gran advenimiento que duró muchos lustros, se acaba con algo tan común como la muerte. Las formas surrealistas que aparentemente son incoherentes retan especialmente al lector que decide abordar este tipo de lecturas. Las innovaciones del siglo XX no son solo de la literatura. Las artes plásticas, la 
música, el teatro, en fin, todas estas formas cultas de expresión empiezan a innovar hasta el punto de ser duramente

criticadas y señaladas con el dedo despectivamente. Por salirse de lo tradicional, por eso fueron tan mal
comprendidas. No me cansaré de decir que se debe seguir la intuitividad que es la objetividad que deben seguir ciertas
normas que hacen inteligible la expresión artística. Muy a pesar de lo mal comprendidas las formas del boom siguen

criticadas y señaladas con el dedo despectivamente. Por salirse de lo tradicional, por eso fueron tan mal
comprendidas. No me cansaré de decir que se debe seguir la intuitividad que es la objetividad que deben seguir ciertas
normas que hacen inteligible la expresión artística. Muy a pesar de lo mal comprendidas las formas del boom siguen

criticadas y señaladas con el dedo despectivamente. Por salirse de lo tradicional, por eso fueron tan mal
comprendidas. No me cansaré de decir que se debe seguir la intuitividad que es la objetividad que deben seguir ciertas
normas que hacen inteligible la expresión artística. Muy a pesar de lo mal comprendidas las formas del boom siguen ciertas normas a pesar de ser revolucionarias.

. ד. 